\title{
Cloning, expression and biochemical characterization of the cholesterol oxidase CgChoA from Chryseobacterium gleum
}

\author{
Renate Reiss, Greta Faccio, Linda Thöny-Meyer and Michael Richter ${ }^{*}$
}

\begin{abstract}
Background: Cholesterol oxidases are important enzymes for applications such as the analysis of cholesterol in clinical samples, the synthesis of steroid derived drugs, and are considered as potential antibacterial drug targets.

Results: The gene choA encoding a cholesterol oxidase from Chryseobacterium gleum DSM 16776 was cloned into the pQE-30 expression vector and heterologously expressed in Escherichia coli JM109 co-transformed with pRARE2. The N-terminally His-tagged cholesterol oxidase ( $\mathrm{CgChoA})$ was assigned to be a monomer in solution by size exclusion chromatography, showed a temperature optimum of $35^{\circ} \mathrm{C}$, and a pH optimum at 6.75 using $0.011 \mathrm{M} \mathrm{MOPS}$ buffer under the tested conditions. The purified protein showed a maximum activity of $15.5 \mathrm{U} / \mathrm{mg}$. CgChoA showed a Michaelis-Menten like kinetic behavior only when the substrate was dissolved in water and taurocholate (apparent $K_{\mathrm{m}}=0.5 \mathrm{mM}$ ). In addition, the conversion of cholesterol by CgChoA was studied via biocatalytic batches at analytical scale, and cholest-4-en-3-one was confirmed as product by HPLC-MS.
\end{abstract}

Conclusion: $\mathrm{CgChoA}$ is a true cholesterol oxidase which activity ranges among the high performing described cholesterol oxidases from other organisms. Thus, the enzyme broadens the available toolbox of cholesterol oxidases for e.g. synthetic and biosensing applications.

Keywords: Chryseobacterium gleum, Cholesterol oxidase, Recombinant expression in Escherichia coli, Biocatalysis, Taurocholate

\section{Background}

Cholesterol oxidase (EC 1.1.3.6, ChoA) is a FAD-dependent bifunctional enzyme that catalyzes the oxidation and isomerization of cholesterol (Figure 1,1 ) to cholest-4-en3-one (3) while dioxygen is finally reduced to $\mathrm{H}_{2} \mathrm{O}_{2}$ as by-product. The enzymatic overall cholesterol oxidation comprises three steps. In the first one the $3 \beta-\mathrm{OH}$ group of cholesterol is oxidized to the corresponding ketone (2) with the concomitant reduction of the FAD cofactor. In a second step an isomerization of the double bond from the $\Delta 5-6$ position to the $\Delta 4-5$ position takes place. The FAD is recycled in a redox reaction with dioxygen, yielding hydrogen peroxide (Figure 1) [1,2]. The substrate range of described ChoA enzymes is not exclusively bound to cholesterol and the conversion of methanol, propan-2-ol

\footnotetext{
* Correspondence: michael.richter@empa.ch

Empa. Swiss Federal Laboratories for Materials Science and Technology, Laboratory for Biomaterials, Lerchenfeldstr. 5, 9014 St. Gallen, Switzerland
}

and allylic alcohols has been described [3,4]. The overall enzyme structure comprises two domains, the FAD binding domain and the substrate binding domain. FAD can either be bound non-covalently (Class I) or linked covalently to a histidine residue of the apoprotein (Class II). A conserved FAD-binding sequence (GxGxGxxxxAxxxxxxG) has been described in the N-terminal region of ChoA from Streptomyces sp., Brevibacterium sp., and Rhodococcus equi [5]. However, the overall amino acid sequences of the two classes do not show high homology [6]. Cholesterol oxidases are found exclusively in bacteria and have been described in various species including Brevibacterium sp., Nocardia erythropolis, Streptomyces sp., Rhodococcus sp., and Pseudomonas fluorescens. The enzymes from these organisms are all commercially available. In some cases the enzyme is secreted (Streptomyces spp., Chromobacterium sp.), but it can also be membrane-bound (Rhodococcus rhodochrous), or be produced intracellularly (Mycobacterium spp.). The enzyme from Brevibacterium sp. has been expressed 


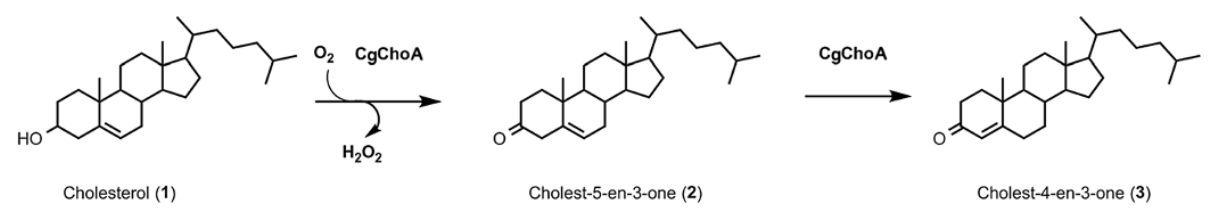

Figure 1 Reaction scheme for the oxidation of cholesterol catalyzed by $\mathrm{CgChoA}$.

recombinantly in E. coli and in Streptomyces lividans [3,7]. Cholesterol oxidase producers can be divided into nonpathogenic bacteria, which use cholesterol as carbon and energy source, and pathogenic bacteria, which utilize cholesterol oxidase for infection by converting the cholesterol of membranes, thus causing damage by altering the physical structure of the membrane [8]. Therefore, and since no eukaryotic enzyme homologues exist, this type of bacterial cholesterol oxidase qualifies as potential target for a new class of antibiotics [9]. An important diagnostic application of the enzyme is the determination of cholesterol in food and blood serum with electrochemical biosensors and based on a cholesterol oxidase-peroxidase coupled reaction $[10,11]$. The enzyme has also been found to be insecticidal, and transgenic plants have been designed with in situ insecticide activity [12]. Moreover, the enzyme has been used as biocatalyst in the synthesis of high value intermediates for industrial steroid drug production and also as tool for studying biological membranes [8,13].

It has been reported that in biotransformation reactions whole cells of Chryseobacterium gleum were successfully used for the biotransformation of cholesterol to androsta1,4-diene-3,17-dione, which is a precursor of antifertility drugs (e.g. estrogens), androgens and the diuretic drug spironolactone $[14,15]$. This strain might therefore be an ideal candidate for strain engineering in order to optimize such biotransformation approaches. In this study, a novel cholesterol oxidase from Chryseobacterium gleum DSM 16776 (CgChoA) was cloned, expressed in E. coli, purified, and biochemically characterized. Moreover, we confirm that enzymatic reactions with purified $\mathrm{CgChoA}$ and cholesterol as substrate yields cholest-4-en-3-one as reaction product by HPLC-MS analysis. The isolated enzyme might thus be useful in fields focused on the biosensing of cholesterol.

\section{Results}

\section{In silico amino acid analysis of ChoA variants}

For the identification of a novel bacterial cholesterol oxidase, a Protein Blast search was performed using the cholesterol oxidase amino acid sequence from Streptomyces sp. (UniProt accession number P12676; PDB code 2GEW) as template. Protein sequences of ChoA were retrieved from public databases, aligned using the ClustalW algorithm of the MegAlign software
(LASERGENE, Madison, USA), and analyzed in order to identify conserved residues possibly important for the catalytic activity. Out of numerous homologues, the gene cho $A$ encoding a hypothetical protein ( $\mathrm{CgChoA})$ annotated as cholesterol oxidase was found in the fully sequenced genome of Chryseobacterium gleum ATCC 35910 (DSM 16776; UniProt accession number D7VYA1). The gene was selected for cloning and recombinant expression in E. coli.

The amino acid sequence of $\mathrm{CgChoA}$ carries the typical sequence of the Rossmann fold $(x h)_{2} G x G x x G x(x x h)_{2}(x)$ ${ }_{8} \mathrm{hxhE}$, where $\mathrm{x}$ is any amino acid and $\mathrm{h}$ an hydrophobic one, between V44 and E70 in the N-terminal region. This indicated that $\mathrm{CgChoA}$ is an FAD-binding protein [2]. Alignment to selected well-studied cholesterol oxidases and phylogenetic analysis indicated a higher similarity of CgChoA to the non-covalent FAD-dependent enzymes belonging to the Class I family (Figure 2). The lack of a signal peptide indicated the intracellular localization of the enzyme in the native host. Using sequence alignment, CgChoA was analyzed for the presence of residues reported to be important for the catalytic activity [4]. More in detail, residues N485 and Y446 (N522 and Y483 in the original protein sequence GenBank: AAA26719.1, respectively) reported to contribute to the stabilization of the cofactor in the reduced form in the cholesterol oxidase from Streptomyces sp. SA-COO were found conserved in CgChoA, e.g. N503 and Y464. Similarly, amino acid E398, corresponding to E361 (E402) in the cholesterol oxidase from Streptomyces sp. SA-COO, that is supposedly involved in the catalytic process by facilitating deprotonation of the substrate was conserved in CgChoA.

The cDNA sequence encoding $\mathrm{CgChoA}$ was cloned into the expression vector $\mathrm{pQE}-30$ such that the final construct $\mathrm{pCgChoA}$ coded for an N-terminal His-tag MRGSHHHHHHGSAC fused to CgChoA. The wild-type CgChoA amino acid sequence (without the His-tag) of $C$. gleum DSM 16776 (UniProt D7VYA1, 528 aa) showed $46.1 \%$ identity to that from Streptomyces sp. (PDB code 2GEW, $540 \mathrm{aa}$ ), $42.8 \%$ identity to that from B. sterolicum (UniProt P22637), 16.1\% to that from Mycobacterium tuberculosis (PDB code 2XKR, 398 aa) and 14.1\% to that from Chromobacterium sp. (PDB code 3JS8, 587 aa). The CgChoA cholesterol oxidase with the N-terminal His-tag consists of 541 amino acids and has a hypothetical molecular mass of $60.4 \mathrm{kDa}$. 


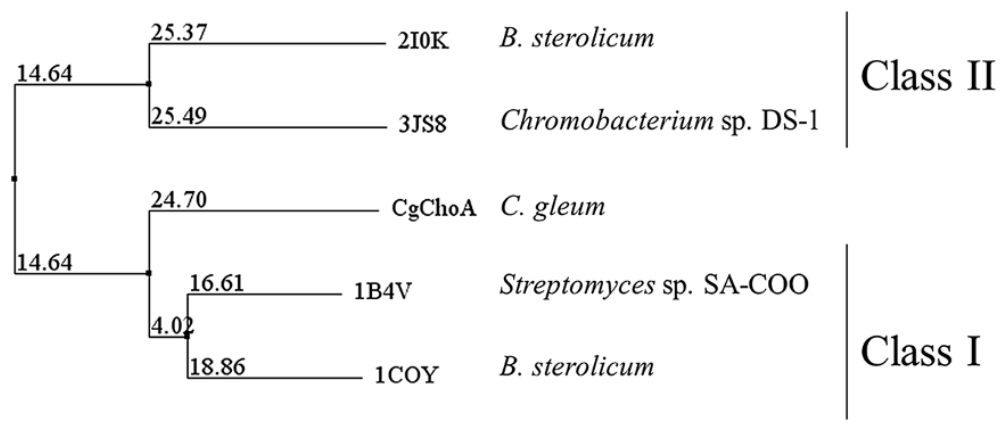

Figure 2 Phylogenetic tree of $\mathrm{CgChoA}$ and selected characterized cholesterol oxidases. The unrooted tree was based on the average distance PID and reports the percentage of identity between each protein sequence vs. the consensus sequence generated from the alignment of all the protein sequences considered. In addition to the enzyme CgChoA (subject of this study), the cholesterol oxidases considered are indicated by their PDB identifier and are the (1COY, cofactor non-covalently bound) and the (2IOK, cofactor covalently bound) flavoproteins from Brevibacterium sterolicum, the flavoprotein from Streptomyces sp. SA-COO (1B4V, cofactor non-covalently bound), and the flavoprotein from Chromobacterium sp. DS-1 (3JS8 cofactor covalently bound). The tree was produced with the software Jalview (www.jalview.org).

\section{Expression of cholesterol oxidase from C. gleum choA in $E$. coli}

The gene choA from C. gleum DSM 16776 contains 8\% rare codons with respect to the codon usage of $E$. coli. Therefore, the expression host E. coli JM109 was additionally transformed with the pRARE2 plasmid, which encodes extra copies of genes coding for tRNAs recognizing the codons AGG, AGA, AUA, CUA, CCC, GGA and CGG. E. coli JM109 cells producing CgChoA in the absence of pRARE2 showed only low activity. In the presence of pRARE2, the cho $A$ gene was expressed at $30^{\circ} \mathrm{C}$, but the protein was found in inclusion bodies. Activity could only be detected in the insoluble fractions. Only when the cultivation temperature was decreased to $16^{\circ} \mathrm{C}$ immediately after induction, soluble and active protein was present.

\section{Protein purification and characterization}

Protein purification was carried out using a Ni-affinity chromatography and subsequently a size exclusion chromatography step. The apparent molecular mass of the expressed $\mathrm{CgChoA}$ was around $60 \mathrm{kDa}$, when visualized on a SDS-polyacrylamide gel (Figure 3). Yields of around $0.2 \mathrm{mg} / \mathrm{L}$ culture of purified and enriched CgChoA were usually obtained. Protein bands obtained in SDS-PAGE were analyzed by tryptic digestion, subsequent MS analyses, and in silico processing using Mascot search program (Functional Genomics Center Zürich). The band above $55 \mathrm{kDa}$ was confirmed to be $\mathrm{CgChoA}$ by tryptic digest and MALDI-MS/MS. The lower band of approximately $30 \mathrm{kDa}$ of lane 3 (Figure 3) was found to be a houskeeping transferase and isomerase as proven by tryptic digestion and MALDI MS/ESI-MS. The molecular mass of the native protein $\mathrm{CgChoA}$ in solution was estimated to be about $85 \mathrm{kDa}$ by size exclusion chromatography on a Superdex 200 pg column. The estimated mass was somewhat higher than $60 \mathrm{kDa}$, but lower than for a theoretical dimer with $120 \mathrm{kDa}$, which indicates that the functional enzyme is rather a monomer than a dimer in solution.

Purified CgChoA had a yellow colour and its spectrum showed the characteristic absorbance peaks of flavinbinding proteins (Figure 3). Heat-treatment was used to assess the possible covalent binding of the flavin cofactor to CgChoA apoprotein [16]. The purified enzyme sample after size exclusion chromatography was boiled in the dark for $5 \mathrm{~min}$ and centrifuged. A spectrum of the supernatant was recorded between 260-700 nm and showed a typical pattern of an FAD spectrum with two absorption maxima at $370 \mathrm{~nm}$ and $470 \mathrm{~nm}$ [17]. Only FAD that is non-covalently associated with the enzyme is detectable by this method, as covalently bound FAD co-precipitates with the protein [16].

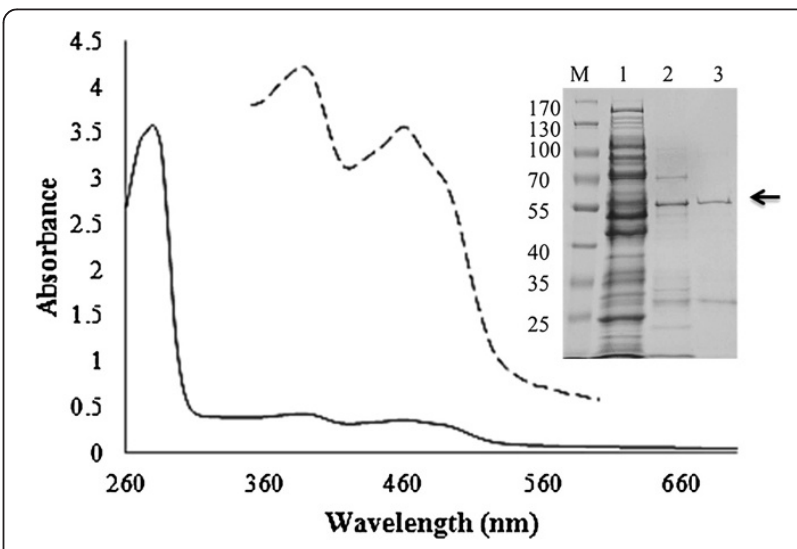

Figure 3 UV-vis absorbance spectrum of purified CgChoA. The typical absorption spectra for FAD was obtained (peaks at $370 \mathrm{~nm}$ and $470 \mathrm{~nm}$; dashed line: 10 fold magnification) [17]. Inset: SDS-PAGE before and after purification of CgChoA. Lane 1: cell free extract; lane 2: protein after IMAC purification; lane 3: purified sample after SEC. The band corresponding to CgChoA is indicated by the arrow. 
After Ni-affinity chromatography, the partially purified protein was subjected to a $\mathrm{pH}$-screen for best activity in different buffers. First, various buffers were tested as shown in Figure 4 (A). As the enzyme performed using 0.11 M MOPS buffer, this buffer was tested between $\mathrm{pH}$ 6-10 and at molarities between $0.55 \mathrm{M}$ and $0.011 \mathrm{M}$. It was found that cholesterol oxidase activity in the coupled assay was highest using $0.011 \mathrm{M}$ MOPS at $\mathrm{pH}$ 6.75, as shown in Figure 4 (B). All subsequent measurements were therefore performed in this buffer. A temperature dependency study was also performed in a similar way. CgChoA maximum activity was measured at around $35^{\circ} \mathrm{C}$ (Figure $4 \mathrm{C}$ ). The $\mathrm{pH}$, molarity and temperature screens were performed with cholesterol oxidase from different purification batches that had been stored for different periods prior to use. Calculated volumetric activities as presented in Figure 4 can therefore not be compared directly. However, the overall trend is valid.

The cholesterol-oxidizing activity of purified CgChoA was assayed at $35^{\circ} \mathrm{C}$ using $0.011 \mathrm{M}$ MOPS, pH 6.75 buffer in a horseradish peroxidase (HRP) coupled assay. 23 cholesterol solutions from $0.17 \mu \mathrm{M}$ to $5.5 \mathrm{mM}$ were prepared and $\mathrm{CgChoA}$ initial activity was determined. We tested ABTS, pyrogallol red and $o$-dianisidine as hydrogen peroxidase substrates and found only minor changes. However, the amount of co-solvent had a significant influence. As control also E. coli JM109 cells transformed with the $\mathrm{pQE}-30$ vector as empty vector control were tested and additionally the E. coli JM109 transformed with pCgChoA after incubation and induction with IPTG as described. After lysis of the cells no conversion of cholesterol could be detected in the empty vector control. No Michaelis-Menten behaviour was found for $\mathrm{CgChoA}$ preparations using cholesterol prepared and diluted in: only water, water with Triton $\mathrm{X}-100$, and water with Triton X-100 and taurocholate, and in these cases and sigmoidal-like curve was obtained when plotting the data obtained (Figure 5). When the substrate was prepared and diluted in water and taurocholate as sole surfactant, a Michaelis-Menten like curve could be fitted and an apparent kinetic constant $K_{\mathrm{m}}$ of $0.5 \mathrm{mM}$ was obtained. For the cholesterol dispersions diluted in water only, a bell-shape profile of the data between 0-0.125 mM cholesterol (see also inset Figure 5) may indicate an activation/deactivation at a low concentration of substrate. A similar activation pattern was found when using a dilution of cholesterol stock solution containing Triton X-100 and taurocholate in water or in water/Triton X-100 and nonionic surfactants and bile acid salts have been described to affect the kinetic behavior at particular enzyme to surfactant ratios [18]. The highest recorded specific activity for CgChoA was $15.5 \mathrm{U} / \mathrm{mg}$.

\section{Enzymatic conversion of cholesterol to cholest-4-en-3-one} Biocatalytic reactions were carried out using purified cholesterol oxidase and cholesterol at a concentration of $1 \mathrm{mM}$ in the presence of $5 \% \mathrm{v} / \mathrm{v}$ Triton X-100. After 42 hours reaction time the product was extracted from the entire reaction batch with chloroform and analyzed. Figure 6 shows the traces monitored by HPLC-DAD at 200 and $250 \mathrm{~nm}$ for the enzymatic reaction. The product cholest-4-en-3-one (3), but not cholesterol (1) shows an
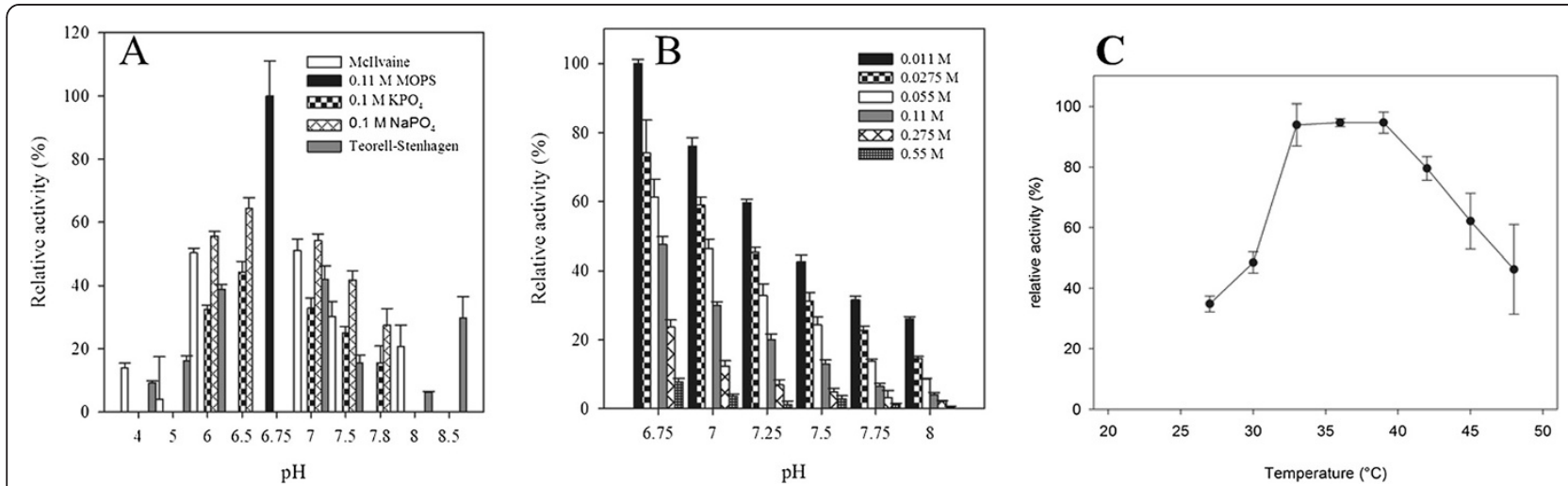

Figure 4 Data obtained from a pH and buffer screen using partially purified cholesterol oxidase from C. gleum. (A) pH and buffer screen using partially purified cholesterol oxidase from $\mathrm{C}$. gleum at $25^{\circ} \mathrm{C}$. The effect of $\mathrm{pH}$ and buffer composition upon initial rates of cholesterol oxidation using the HRP coupled cholesterol oxidation assay with ABTS as electron donor was investigated. All data points represent mean values \pm SEM from triplicate determinations. $100 \%$ corresponds to $3.8 \mathrm{U} / \mathrm{L}$. (A) pH and buffer screen at $25^{\circ} \mathrm{C}$. (B) MOPS buffer screen using partially purified cholesterol oxidase from C. gleum at $25^{\circ} \mathrm{C}$ The effect of $\mathrm{pH}$ and molarity upon initial rates of cholesterol oxidation using the HRP coupled cholesterol oxidation assay with ABTS as electron donor was investigated. All data points represent mean values \pm SEM from triplicate determinations. $100 \%$ corresponds to 29.6 U/L. (C) Temperature dependency study of cholesterol oxidase activity from C. gleum in 0.11 M MOPS buffer, pH 6.75. The oxidation of cholesterol as a function of temperature is given relative to the highest activity recorded (47.0 U/L) that was taken as $100 \%$. All data points represent mean values \pm SEM from triplicate determinations. 


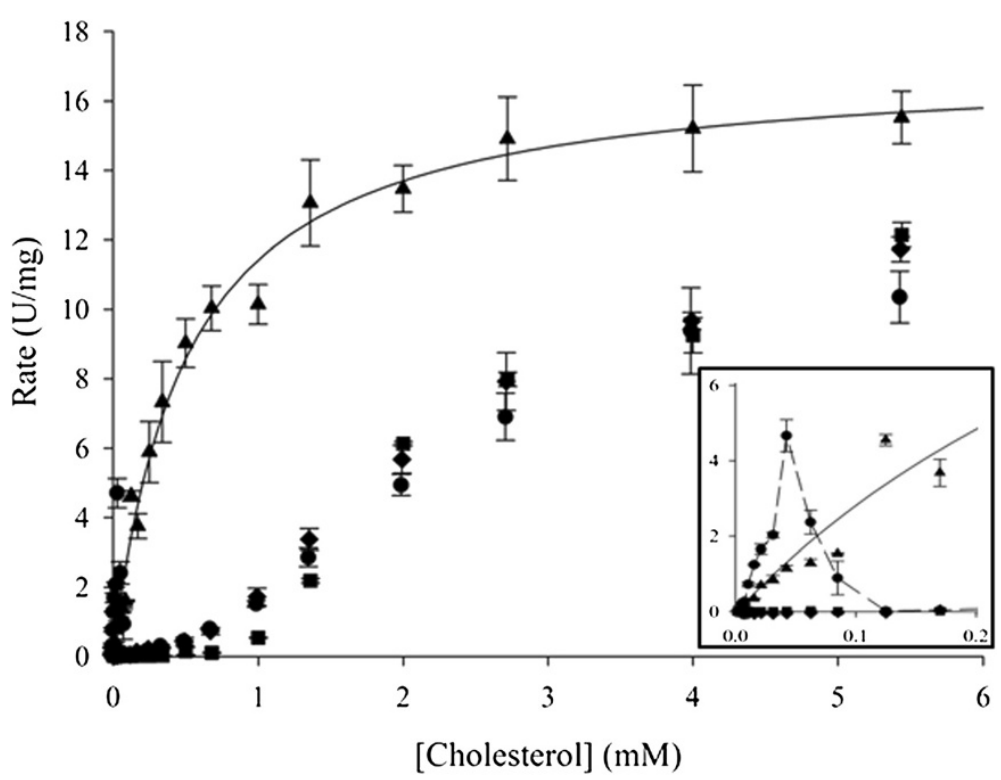

Figure 5 Kinetic plot obtained with recombinant CgChoA from C. gleum. The specific activity (U/mg) was plotted versus the substrate concentration. An enzyme concentration of $3.57 \mathrm{mg} / \mathrm{L}$ was used and the cholesterol stock solution/dispersion was prepared and serially diluted in

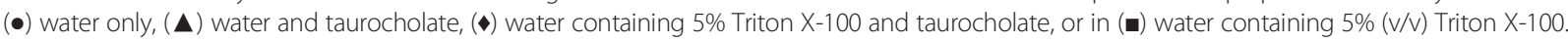

absorbance at $250 \mathrm{~nm}$. The peak of the chromatogram at $14.4 \mathrm{~min}$ at $200 \mathrm{~nm}$ corresponds to cholesterol with a mass signal of $m / z 369.2\left[\mathrm{M}-\mathrm{H}_{2} \mathrm{O}+\mathrm{H}\right]^{+}$. The peak of the chromatogram at $13.1 \mathrm{~min}$ at 200 and $250 \mathrm{~nm}$ corresponds to cholest-4-en-3-one (3) with a mass signal of $\mathrm{m} / \mathrm{z} 385.1$ $[\mathrm{M}+\mathrm{H}]^{+}$and was only found in the reaction batch which contained cholesterol oxidase. Signals at $4.5 \mathrm{~min}$ derived from Triton X-100. There the mass pattern typical for PEG derivatives (series of mass signals differing in $\Delta m / z 44$ ) was observed. The HPLC-MS analysis was performed for qualitative detection of the cholesterol conversion by CgChoA. Additional background signals could not be assigned to relevant compounds by MS. Commercially available cholesterol and cholest-4-en-3-one were used as reference substances.

\section{Discussion}

Searching for novel cholesterol oxidases is of great interest in fields such as biosensing and enzymatic synthesis. The oxidation of cholesterol to cholest-4-en-3-one has been reported for cholesterol oxidase from whole cells of $C$. gleum, Bacillus subtilis and Streptomyces sp. [13,14,19]. Especially those enzymes with considerable low amino acid homology to already described ones may have novel optimal working conditions and thus be suitable for innovative applications.

With an approach similar to what reported for the production of other cholesterol oxidases (Table 1), the gene coding for CgChoA was cloned into pQE-30 and expressed in $E$. coli in the presence of pRARE2 to produce an enzyme with an N-terminal His-tag.
The reduction of temperature to $16^{\circ} \mathrm{C}$ post induction was necessary to obtain soluble protein. The $\mathrm{CgChoA}$ was purified and found to occur presumably as a monomer, like cholesterol oxidase from Brevibacterium sp. and other bacteria $[9,20]$. A maximum specific cholesterol oxidase activity of $15.5 \mathrm{U} / \mathrm{mg}$ was found, which is in the same range of other recombinantly expressed cholesterol oxidases (Table 1). A maximum specific activity of 16.7 and 3.7 U/mg has been described for Chromobacterium sp. and Brevibacterium sp. (Table 1) respectively, both expressed without a His-tag [21,22]. Cholesterol oxidase from Brevibacterium sp. expressed with an $\mathrm{N}$ - or C-terminal His-tag, however, showed reduced activity for each construct when compared to the non-tagged enzyme [23]. It is therefore possible that a higher specific activity might be reached with a non His-tagged CgChoA and after more extensive purification. However, since the activity of the His-tagged enzyme was sufficient for characterization, we did not further investigate a non-tagged CgChoA.

The recombinant CgChoA was active between $\mathrm{pH}$ 4-8 with optimal activity in the neutral range similarly to other cholesterol oxidases (Table 1), e.g. at $\mathrm{pH} 6.75$ using 0.011 M MOPS buffer for the coupled HRP assay. At higher concentrations of MOPS, the activity declined steadily at any of the $6 \mathrm{pH}$ values measured. MOPS buffer with a $\mathrm{pH}$ lower than 6.75 has not been tested as it buffers only between 6.5 and 8 . A temperature optimum between $32^{\circ} \mathrm{C}$ and $40^{\circ} \mathrm{C}$ was found, which is in the range of the cholesterol oxidase from Corynebacterium cholesterolicum, but lower than that of Streptomyces violascens or Brevibacterium sp. enzymes, which showed 


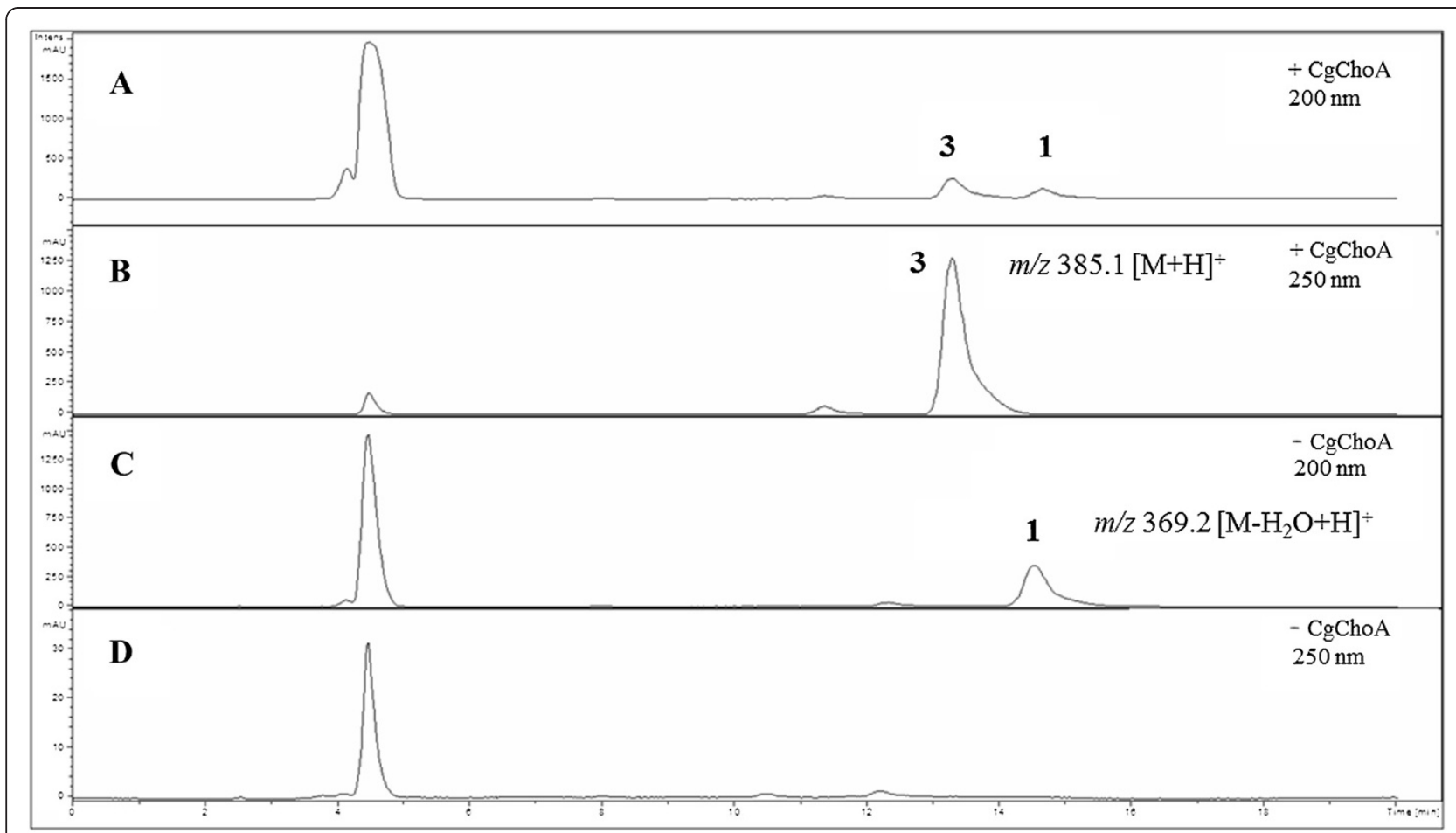

Figure 6 Chromatograms after subjecting the extracted samples to HPLC-MS measurements: cholesterol (1) and oxidation product cholest-4-en-3-one (3). Shown profiles are extracted at 200 and $250 \mathrm{~nm}$ from the DAD-signal for the reaction with CgChoA (A and B, respectively) and without enzyme (C and $\mathbf{D}$, respectively); $m / z$ signals are indicated.

optimum activity at around $50^{\circ} \mathrm{C}[5]$. The activity data obtained when the substrate was dissolved in the presence of Triton X-100 and/or water only could not be fitted to the Michaelis-Menten equation, which is only applicable for enzymatic reactions in homogeneous solutions and therefore cannot be directly adapted to the heterogeneous reaction conditions that were applied here. The presence of the anionic surfactant taurocholate proved to affect the measured activity and an apparent $K_{\mathrm{m}}$ of $0.5 \mathrm{mM}$ was obtained for CgChoA and the substrate cholesterol. We cannot exclude for taurocholate an effect not only regarding an improved substrate solubilisation, and thus enhanced accessibility to the enzyme, but also an effect on the enzyme itself. In summary, the anionic surfactant taurocholate is sufficient as additive for monitoring the enzyme activity of $\mathrm{CgChoA}$ with regard to the natural substrate cholesterol, while the presence of the non-ionic additive Triton X-100 did not affect the general kinetic behaviour. These data may be of special interest for developing biosensors for samples with at low cholesterol content as dilution in the presence of taurocholate might provide a linear correlation between the substrate concentration and the signal measured.

\section{Conclusions}

The cholesterol oxidase CgChoA from C. gleum was successfully expressed in E. coli JM109 co-transformed with pCgChoA and pRARE2. The CgChoA carrying an $\mathrm{N}$-terminal His-tag was purified and subjected to a $\mathrm{pH}$ and temperature screen. The highest specific activity was determined to be $15.5 \mathrm{U} / \mathrm{mg}$. Michaelis-Menten type kinetics could only be observed in the presence of taurocholate as single surfactant within the enzymatic assay. The CgChoA cholesterol oxidation product was identified as cholest-4-en-3-one by direct and rapid detection via HPLC-MS. The rapid and robust HPLC-MS assay developed in this study enables a more detailed study of $\mathrm{CgChoA}$ and other cholesterol oxidases. The described enzyme complements the set of available cholesterol oxidases for diverse applications such as bionsensing and synthesis of intermediates for drug synthesis. As successful biotransformation employing $C$. gleum as host organism has already been demonstrated [14], the future engineering of $\mathrm{CgChoA}$ for a broader substrate specificity might enable the application of this enzyme for the conversion of other steroid compounds.

\section{Methods}

\section{Bacterial strains}

Chryseobacterium gleum DSM 16776 was obtained from the German collection of microorganisms (DSMZ). E. coli strain JM109 [genotype endA1 recA1, gyrA96, thi, hsdR17, $\left(\mathrm{r}_{\mathrm{K}}{ }^{-}, \mathrm{m}_{\mathrm{K}}{ }^{+}\right)$, relA1, supE44, $\lambda^{-}, \Delta$ (lac-proAB), ( $\mathrm{F}^{\prime}$, traD36, pro $A B$, $\left.\left.\operatorname{lacl}^{\mathrm{q}} \mathrm{Z} \Delta \mathrm{M} 15\right)\right]$ and the $\mathrm{pQE}-30$ expression vector 
Table 1 Comparison of different aspects concerning the production and selected properties of cholesterol oxidases

\begin{tabular}{|c|c|c|c|c|c|c|}
\hline Source (UniProt ID) & $\begin{array}{l}\text { MW } \\
(\mathrm{kDa})\end{array}$ & Expression system $^{a}$ & Purification steps $^{\text {b }}$ & Activity asssay ${ }^{b}$ & $\begin{array}{l}\text { Specific activity on } \\
\text { cholesterol (U/mg) }\end{array}$ & Refs. \\
\hline Brevibacterium sterolicum (Q7SID9) & 61.52 & $\begin{array}{l}\text { pET24b(+), E. coli BL21(DE3) } \\
\text { pLysS, TB }+20 \mathrm{~mL} / \mathrm{L} \text { glycerol, } \\
25 / 30^{\circ} \mathrm{C}\end{array}$ & HiTrap (IMAC) & $\begin{array}{l}\text { Potassium phosphate buffer } \mathrm{pH} 7.5 \text { at } 25^{\circ} \mathrm{C} \\
\text { (propan-2-ol and Thesit) monitoring } \mathrm{H}_{2} \mathrm{O}_{2} \\
\text { production using HRP and o-dianisidine }\end{array}$ & 7 (crude extract) & {$[6,24]$} \\
\hline $\begin{array}{l}\text { Brevibacterium sterolicum nov. sp. } \\
\text { ATCC21387 }\end{array}$ & 46.50 & pUC19, E. coli MM294, LB, 30 C & $\begin{array}{l}\text { Ammonium sulfate precipitation, } \\
\text { DEAE-cellulose, Superose, } \\
\text { hydroxyapatite }\end{array}$ & $\begin{array}{l}\text { Sodium phosphate buffer } \mathrm{pH} 7.0,37^{\circ} \mathrm{C} \\
\text { (Triton } \mathrm{X} \text { - } 100 \text { ), monitoring } \mathrm{H}_{2} \mathrm{O}_{2} \text { production } \\
\text { coupled to 4-aminoantipyrine and phenol } \\
\text { via HRP }\end{array}$ & 55.2 & [25] \\
\hline \multirow{2}{*}{$\begin{array}{l}\text { Brevibacterium sterolicum nov. sp. } \\
\text { ATCC21387 (Q212N2) }\end{array}$} & \multirow[t]{2}{*}{59.07} & \multirow{2}{*}{$\begin{array}{l}\text { pET28a(+), E. coli BL21(DE3), } \\
\mathrm{LB}, 28^{\circ} \mathrm{C}\end{array}$} & \multirow{2}{*}{$\begin{array}{l}\text { Affinity chromato-graphy, } \\
\text { (riboflavin bound to, Sepharose 4B) }\end{array}$} & \multirow{2}{*}{$\begin{array}{l}\text { Quantifying } \mathrm{H}_{2} \mathrm{O}_{2} \text { by coupling to } \mathrm{HRP} \\
\text { reaction with aminopyrine, } 37^{\circ} \mathrm{C}\end{array}$} & 15.5 & [20] \\
\hline & & & & & (3.7, with His tag) & [22] \\
\hline Chromobacterium sp. DS-1 (B5MGF) & 63.00 & $\begin{array}{l}\text { pET-21d(+), E. coli Rosetta, } \\
\text { LB, } 30^{\circ} \mathrm{C}\end{array}$ & $\begin{array}{l}\text { Heat purification at } 70^{\circ} \mathrm{C} \text { for } 30 \mathrm{~min} \text {, } \\
\text { DEAE-cellulose DE } 52\end{array}$ & $\begin{array}{l}\text { Sodium potassium phosphate buffer pH7.0, } \\
30^{\circ} \mathrm{C} \text { (sodium cholate, Triton X-100), } \\
\text {-aminoantipyrine, phenol, HRP }\end{array}$ & 16.7 & {$[21,26]$} \\
\hline Chryseobacterium gleum (D7VYA1) & 59.00 & $\begin{array}{l}\text { pQE30 (pRARE2), E. coli } \\
\text { JM109, modified M9, } 16^{\circ} \mathrm{C}\end{array}$ & $\begin{array}{l}\text { HisTrap FF (IMAC), SEC on Superdex } \\
200 \text { pg }\end{array}$ & $\begin{array}{l}\text { HPLC assay and coupled enzyme assay } \\
\text { MOPS buffer, pH } 6.75,37^{\circ} \mathrm{C}, \text { HRP and ABTS } \\
\text { (Triton X-100 and taurocholic acid) }\end{array}$ & 15.5 & this study \\
\hline Streptomyces sp. SA-COO (P12676) & 58.99 & $\begin{array}{l}\text { pUC19, E. coli BL21(DE3) } \\
\text { plysS, 2YT, } 28^{\circ} \mathrm{C}\end{array}$ & $\begin{array}{l}\text { Butyl-Sepharose column chromatography, } \\
\text { DEAE-cellulose column chromatography }\end{array}$ & $\begin{array}{l}\text { Formation rate of } \mathrm{H}_{2} \mathrm{O}_{2} \text { was monitored in } \\
\text { a coupled assay with } \mathrm{HRP} \text { and } \mathrm{ABTS}, 37^{\circ} \mathrm{C} \\
\text { (Triton } \mathrm{X}-100, \mathrm{BSA} \text { ) }\end{array}$ & - & {$[10,27,28]$} \\
\hline
\end{tabular}

Data taken from the Brenda database (www.brenda-enzymes.org/), RCSB Protein data bank (pdb) and indicated references (refs.).

a vector, host, expression strain, cultivation medium, cultivation conditions.
${ }^{\mathrm{b}}$ Abbreviations: $A B T S$ 2,2'-azino-bis(3-ethylbenzothiazoline-6-sulphonic acid), BSA bovine serum albumin, HRP horseradish peroxidase, IMAC Immobilized metal ion affinity chromatography, SEC size-exclusion chromatography. 
were purchased from Promega (Madison, USA) and Qiagen (Valencia, USA), respectively. The origin of replication in pQE-30 is ColE1 (pBR322) and transcription of the inserted gene is controlled by the bacteriophage $\mathrm{T} 5$ promoter (recognized by the E. coli housekeeping RNA polymerase) and two lac operator sequences (conferring inducibility by IPTG). For efficient repression the host strain JM109 which over-expresses the LacI repressor was used. JM109 was transformed with the plasmid pRARE2, which contains the tRNA genes $\arg U$, $\arg W$, ileX, glyT, leuW, proL, metT, thrT, tyrU, thrU and $\operatorname{argX}$. The usage of the rare codons AGG, AGA, AUA, CUA, CCC, GGA and CGG is thereby supplemented. The plasmid was isolated from Rosetta2 (DE3) (Merck Chemicals, UK) $\left(\mathrm{F}^{-}\right.$ompT $h s d S_{\mathrm{B}}\left(\mathrm{r}_{\mathrm{B}}^{-} \mathrm{m}_{\mathrm{B}}^{-}\right)$gal dcm (DE3) pRARE2) cells. The resulting chloramphenicol-resistant strain JM109-pRARE2 was the expression host.

\section{Cloning of choA from C. gleum}

The putative cholesterol oxidase gene choA of C. gleum was identified by Protein blast (NCBI website) using the cholesterol oxidase sequence of Streptomyces sp. (UniProt accession no. P12676) as search template. The cholesterol oxidase gene of C. gleum (accession no. ACKQ02000004) was PCR amplified from genomic DNA with forward primer 5' GCG GCA TGC GAC AGA AAA AAA TTC ATC AGG ACA AGT GC 3' (introducing a SphI site around the native start codon) and reverse primer 5' CCG AAG CTT TTA ACC CAG GTT AAA TTC ATT TTG CCG G 3' (introducing a HindIII site after the native stop codon). PCR was performed with high fidelity Phusion polymerase (New England Biolabs, Ipswich, USA) and a diluted solution of genomic DNA of C. gleum DSM 16776 as template source. Genomic DNA was isolated using the GenElute Bacterial genomic DNA kit (Sigma-Aldrich, $\mathrm{CH})$. Plasmid DNA and PCR products were purified using the Gene Jet Plasmid Miniprep Kit (Fermentas) and the GenElute PCR clean-up kit (Sigma-Aldrich). DNA from agarose gels was recovered using the GenElute Gel extraction kit (Sigma-Aldrich, CH). The 1596 bp PCR product was cloned into the $\mathrm{pQE}-30$ expression vector in frame with a sequence coding for an $\mathrm{N}$-terminal hexa-histidine tag to allow purification by immobilized metal affinity chromatography. The in frame cloning of the choA gene from C. gleum DSM 16776 in the final expression plasmid $\mathrm{pCgChoA}$ was confirmed by DNA sequencing (GATC, Germany).

\section{Cell cultivation and protein purification}

C. gleum DSM 16776 was grown overnight at $30^{\circ} \mathrm{C}$ at 180 $\mathrm{rpm}$ in trypticase soy yeast extract medium (trypticase soy broth $30 \mathrm{~g} / \mathrm{L}$, yeast extract $3 \mathrm{~g} / \mathrm{L}$ ). E. coli JM109-pRARE2 was transformed with pCgChoA. Expression of the recombinant protein was performed in medium containing
$1 \times$ M9 salts, $20 \mathrm{~g} / \mathrm{L} \mathrm{N}$-Z-amine, $20 \mathrm{~g} / \mathrm{L}$ glycerol, $1 \mathrm{mM}$ $\mathrm{MgSO}_{4}, 1 \mathrm{mM} \mathrm{MgCl} 2,100 \mu \mathrm{M} \mathrm{CaCl} 2,100 \mu \mathrm{M}$ thiamine, $0.025 \%$ glucose and trace metal mixture [29]. A $100 \mathrm{~mL}$ overnight culture was grown from a single colony (LB agar) and used to inoculate $700 \mathrm{~mL}$ of medium (dilution 1:50). The culture was grown at $37^{\circ} \mathrm{C}$ with shaking at $180 \mathrm{rpm}$. At an $\mathrm{OD}_{600}=0.8$, protein production was induced at $0.1 \mathrm{mM}$ isopropyl thio- $\beta$-D-galactoside (IPTG). At the same time, the temperature and shaking were reduced to $16^{\circ} \mathrm{C}$ and $120 \mathrm{rpm}$ for $16-18$ hours. For plasmid selection $100 \mu \mathrm{g} / \mathrm{mL}$ ampicillin and $20 \mu \mathrm{g} / \mathrm{mL}$ chloramphenicol were added to plates and liquid media. For protein purification cells were harvested by centrifugation at $4^{\circ} \mathrm{C}$ for $30 \mathrm{~min}$ at $4,495 \times \mathrm{g}$, washed in $0.1 \mathrm{M}$ sodium phosphate buffer $\mathrm{pH} 7$, centrifuged again and subsequently stored at $-20^{\circ} \mathrm{C}$. Frozen cells were thawed on ice and resuspended in $0.1 \mathrm{M}$ sodium phosphate buffer $\mathrm{pH} 7$ with $20 \mathrm{mM}$ imidazole and $0.5 \mathrm{M}$ sodium chloride (buffer A) containing $1 \mathrm{mg} / \mathrm{mL}$ lysozyme and protease inhibitor mix (Roche Complete Protease Inhibitor Mix, EDTA-free) and re-frozen at $-80^{\circ} \mathrm{C}$. Cells were thawed, Benzonase Nuclease (Roche) was added and the suspension incubated for $1 \mathrm{~h}$ at $37^{\circ} \mathrm{C}$ at $120 \mathrm{rpm}$. The suspension was subjected to twelve $10 \mathrm{~s}$ rounds of sonication with a Branson sonicator equipped with a microtip at a setting of $80 \%$. Cellular debris was removed by centrifugation at $4^{\circ} \mathrm{C}$ for $40 \mathrm{~min}, 47,000 \times \mathrm{g}$. Purification was performed on an Äkta purifier FPLC system (GE-Healthcare). The sample was loaded onto a $1 \mathrm{~mL}$ HisTrap FF chromatography column (GE-Healthcare), previously equilibrated with buffer A. Proteins were eluted with a imidazole gradient from 0 to $1 \mathrm{M}$. Fractions displaying cholesterol activity were pooled and concentrated by ultrafiltration using a $30 \mathrm{kDa}$ cut-off. The sample was loaded onto a Superdex 200 column (GE-Healthcare), previously equilibrated with $20 \mathrm{mM}$ MOPS buffer $\mathrm{pH} 6.75$ containing $0.1 \mathrm{M} \mathrm{NaCl}$. Fractions with cholesterol oxidase activity were pooled and concentrated by ultrafiltration. The purity of the sample was analyzed by SDS-PAGE using a $10 \%$ polyacrylamide gel. The gel filtration kit (GE-Healthcare) was used to calibrate a Superdex 200 column with high and low molecular weight standards, previously equilibrated with $20 \mathrm{mM}$ MOPS buffer ( $\mathrm{pH}$ 6.75) containing $0.1 \mathrm{M} \mathrm{NaCl}$.

\section{Activity assay and protein determination}

A $27.2 \mathrm{mM}$ stock solution/dispersion of cholesterol was prepared and diluted in water in the presence or absence of $5 \%(\mathrm{v} / \mathrm{v})$ Triton X-100, 2.9\% (w/v) of taurocholic acid sodium salt (Sigma Aldrich), and a combinations thereof. Cholesterol oxidase activity was assayed by quantifying $\mathrm{H}_{2} \mathrm{O}_{2}$ formation from the coupling reaction with HRP. The activity assay mixture contained $40 \mu \mathrm{L}$ of cholesterol at the selected concentration, $10 \mu \mathrm{L}$ 
of HRP (concentration $1 \mathrm{mg} / \mathrm{mL}$, in $\mathrm{ddH}_{2} \mathrm{O}$ ), $10 \mu \mathrm{L}$ of ABTS (concentration $10 \mathrm{mM}$, in $\mathrm{ddH}_{2} \mathrm{O}$ ), $110 \mu \mathrm{L}$ of 0.011 M MOPS buffer pre-heated to $37^{\circ} \mathrm{C}$, and $30 \mu \mathrm{L}$ of the purified enzyme preparation in a total volume of $200 \mu \mathrm{L}$. The spectrophotometric cholesterol activity assay was carried out in a 96-well plate using a BioTek Synergy Mx spectrophotometer. ABTS $(0.6 \mathrm{mM})$, pyrogallol red $(0.15 \mathrm{mM})$ and $o$-dianisidine $(0.5 \mathrm{mM})$ were used as substrates for the HRP coupled assay using $0.011 \mathrm{M}$ MOPS buffer $\mathrm{pH} 6.75$ at $37^{\circ} \mathrm{C}$. The reaction was started by adding cholesterol oxidase and followed for oxidation of ABTS at $420 \mathrm{~nm}\left(\varepsilon=36000 \mathrm{M}^{-1} \mathrm{~cm}^{-1}\right)$, of pyrogallol red at $550 \mathrm{~nm}\left(\varepsilon=30900 \mathrm{M}^{-1} \mathrm{~cm}^{-1}\right)$ and of $o$-dianisidine at $440 \mathrm{~nm}\left(\varepsilon=13000 \mathrm{M}^{-1} \mathrm{~cm}^{-1}\right)$. Kinetic parameters of cholesterol oxidase samples were determined between $0.17 \mu \mathrm{M}-5.5 \mathrm{mM}$ cholesterol at $35^{\circ} \mathrm{C}$, and results were analyzed with the Enzyme Kinetics Module of the software SigmaPlot (Systat Software Inc., CA, USA).

Cholesterol activity as a function of the $\mathrm{pH}$ was recorded via the HRP coupled assay with $0.5 \mathrm{mM} \mathrm{ABTS}$ and $0.55 \mathrm{mM}$ cholesterol using Teorell-Stenhagen buffer ( $\mathrm{pH}$ 4.0, 5.0, 6.0, 7.0, 7.5, 8.0, and 8.5), $0.1 \mathrm{M}$ sodium phosphate buffer ( $\mathrm{pH} 6.0,6.4,7.0,7.5$, and 7.8), $0.11 \mathrm{M}$ MOPS $\mathrm{pH}$ 6.75, 0.1 M potassium phosphate buffer ( $\mathrm{pH}$ 6.0, 6.5, 7.0, 7.5, and 7.8), and McIlvaine buffer ( $\mathrm{pH} 4.0,5.0,6.0$, 7.0, 7.5, and 8.0). Further $0.55 \mathrm{M}, 0.275 \mathrm{M}, 0.11 \mathrm{M}$ $0.055 \mathrm{M}, 0.0275 \mathrm{M}$ and 0.011 M MOPS buffers (pH 6.75, 7, $7.25,7.5,7.75$, and 8.0 ) were tested. The temperature optimum was recorded between 24 and $48^{\circ} \mathrm{C}$ following ABTS oxidation with $0.55 \mathrm{mM}$ cholesterol, in an assay volume of $3 \mathrm{~mL}$ using a magnetically stirred, temperature-controlled cuvette device using a Varian Cary 50 Bio spectrophotometer. Total protein concentration was determined by the method of Bradford, with bovine serum albumin as standard.

\section{Biocatalytic reactions}

The substrate cholesterol was added from a stock solution, which was made up as described above (containing Triton X-100 and taurocholate), to a final concentration of $1 \mathrm{mM}$ in $0.011 \mathrm{M}$ MOPS buffer $\mathrm{pH}$ 6.75. The reaction was adjusted to $600 \mu \mathrm{L}$ and $0.04 \mathrm{mg}$ of purified cholesterol oxidase from C. gleum was added $(0.67 \mathrm{U} / \mathrm{mL})$. For the blank reaction water was used instead of enzyme solution. All reactions were prepared in triplicate. The reaction mixture was left shaking at $250 \mathrm{rpm}$ at $30^{\circ} \mathrm{C}$ for 42 hours in $3 \mathrm{~mL}$ screw cap glass vials.

Analysis of cholesterol and cholest-4-en-3-one by HPLC-MS The total reaction was extracted on $1 \mathrm{~mL}$ chloroform. After evaporation of the solvent at room temperature, the product was dissolved in the solvent, which was the same as the mobile phase used for HPLC. $10 \mu \mathrm{L}$ of the analyte sample were injected into a Phenomenex

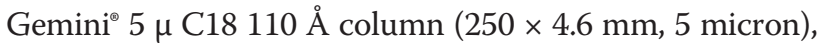
and chromatography under isocratic conditions was performed using methanol:water 100:2 (v/v) at a flow rate of $0.8 \mathrm{~mL} / \mathrm{min}$ at room temperature. Cholesterol and cholest-4-en-3-one were purchased from Sigma-Aldrich and used as reference. Product formation was monitored at 200 and $250 \mathrm{~nm}$, whereas cholesterol was detected at $200 \mathrm{~nm}$. The Agilent HPLC 1100 system equipped with a DAD was coupled to an esquireHCT ion trap mass spectrometer (Bruker. Germany), and an atmospheric pressure chemical ionization (APCI) source was operated in the positive ion mode. Conditions were as follows: scan range, $m / z 50-600$; dry gas flow of $11 \mathrm{~L} / \mathrm{min}$, nebulizer pressure $35 \mathrm{psi}$, drying gas temperature $320^{\circ} \mathrm{C}$ and the APCI heater temperature was $350^{\circ} \mathrm{C}$. The extracted ion current (EIC) signals were deduced based on the exact masses for protonated cholesterol after water elimination $(m / z 369.34)$ as well as for the protonated oxidation product cholest-4-en-3-one $(m / z 385.34)$.

\section{Abbreviations}

ABTS: 2,2'-Azino-bis 3-ethylbenzothiazoline-6-sulphonic acid; APCI: Atmospheric pressure chemical ionization; CgChoA: Cholesterol oxidase from Chryseobacterium gleum; HRP: Horseradish peroxidase.

\section{Competing interests}

The authors declare that they have no competing interests.

\section{Authors' contributions}

RR participated in the design of the study, carried out the experiment and in writing the manuscript. GF confirmed the kinetic study and contributed to the preparation of the revised manuscript. MR participated in the design of the study, carried out the HPLC-MS analysis and helped to draft the manuscript. LTM provided financial and administrative support and participated in the design of the study and writing the manuscript. All authors read and approved the final manuscript.

\section{Acknowledgments}

We thank Thomas Ramsauer, Flavia Zuber and Nadja Schulthess for technical assistance. This project was evaluated by the Swiss National Foundation and funded by Nano-Tera.ch with Swiss Confederation financing.

Received: 7 June 2013 Accepted: 25 March 2014

Published: 21 May 2014

\section{References}

1. Vrielink A, Ghisla S: Cholesterol oxidase: biochemistry and structural features. Febs Journal 2009, 276(23):6826-6843.

2. Dym O, Eisenberg D: Sequence-structure analysis of FAD-containing proteins. Protein Sci 2001, 10(9):1712-1728.

3. Aparicio JF, Martin JF: Microbial cholesterol oxidases: bioconversion enzymes or signal proteins? Mol Biosyst 2008, 4(8):804-809.

4. Vrielink A: Cholesterol oxidase: structure and function. Subcell Biochem 2010, 51:137-158.

5. Kumari L, Kanwar SS: Cholesterol Oxidase and Its Applications. Advances in Microbiology 2012, 2(2):49-65

6. Volonte F, Pollegioni L, Molla G, Frattini L, Marinelli F, Piubelli L: Production of recombinant cholesterol oxidase containing covalently bound FAD in Escherichia coli. Bmc Biotechnology 2010, 10:33.

7. Ohta T, Fujishiro K, Yamaguchi K, Uwajima T, Aisaka K, Hasegawa M: Hyperexpression and Analysis of $c h o B$ Encoding Cholesterol Oxidase of Brevibacterium sterolicum in Escherichia coli and Streptomyces lividans. Biosci Biotechnol Biochem 1992, 56(11):1786-1791.

8. Kreit J, Sampson NS: Cholesterol oxidase: physiological functions. Febs Journal 2009, 276(23):6844-6856. 
9. Caldinelli L, lametti S, Barbiroli A, Bonomi F, Fessas D, Molla G, Pilone MS, Pollegioni L: Dissecting the structural determinants of the stability of cholesterol oxidase containing covalently bound flavin. J Biol Chem 2005, 280(24):22572-22581.

10. Doukyu N: Characteristics and biotechnological applications of microbial cholesterol oxidases. Appl Microbiol Biotechnol 2009, 83(5):825-837.

11. Pollegioni L, Piubelli L, Molla G: Cholesterol oxidase: biotechnological applications. Febs Journal 2009, 276(23):6857-6870.

12. Corbin DR, Grebenok RJ, Ohnmeiss TE, Greenplate JT, Purcell JP: Expression and chloroplast targeting of cholesterol oxidase in transgenic tobacco plants. Plant Physiol 2001, 126(3):1116-1128.

13. Guo LW, Wilson WK, Pang JH, Shackleton CHL: Chemical synthesis of 7- and 8-dehydro derivatives of pregnane-3,17 alpha,20-triols, potential steroid metabolites in Smith-Lemli-Opitz syndrome. Steroids 2003, 68(1):31-42.

14. Chaudhari PN, Chaudhari BL, Chincholkar SB: Cholesterol biotransformation to androsta-1,4-diene-3,17-dione by growing cells of Chryseobacterium gleum. Biotechnol Lett 2010, 32(5):695-699.

15. Dogra N, Qazi GN: Steroid biotransformation by different strains of Micrococcus sp. Folia Microbiologica 2001, 46(1):17-20.

16. Munro AW, Noble MA: Fluorescence analysis of Flavoproteins. In Flavoprotein protocols, Volume 131. Edited by Chapman SK, Reid GA. Totawa, N.J: Humana Press; 1999.

17. Gadda G, Wels G, Pollegioni L, Zucchelli S, Ambrosius D, Pilone MS, Ghisla S: Characterization of cholesterol oxidase from Streptomyces hygroscopicus and Brevibacterium sterolicum. Eur J Biochem 1997, 250(2):369-376.

18. Pollegioni L, Gadda G, Ambrosius D, Ghisla S, Pilone MS: Cholesterol oxidase from Streptomyces hygroscopicus and Brevibacterium sterolicum: effect of surfactants and organic solvents on activity. Biotechnol Appl Biochem 1999, 30:27-33.

19. Kim KP, Rhee $\mathrm{CH}$, Park HD: Degradation of cholesterol by Bacillus subtilis SFF34 isolated from Korean traditional fermented flatfish. Lett Appl Microbiol 2002, 35(6):468-472.

20. Xin Y, Yang HL, Xia XL, Zhang L, Cheng C, Mou GC, Shi JB, Han YF, Wang W: Affinity purification of a cholesterol oxidase expressed in Escherichia coli. J Chromatogr B Analyt Technol Biomed Life Sci 2011, 879(13-14):853-858.

21. Doukyu N, Shibata K, Ogino H, Sagermann M: Cloning, sequence analysis, and expression of a gene encoding Chromobacterium sp. DS-1 cholesterol oxidase. Appl Microbiol Biotechnol 2009, 82(3):479-490

22. Wang L, Wang W: Coenzyme precursor-assisted expression of a cholesterol oxidase from Brevibacterium sp. in Escherichia coli. Biotechnol Lett 2007, 29(5):761-766.

23. Xin $Y$, Yang $H L$, Xia XL, Zhang L, Zhang YR, Tong YJ, Chen Y, Wang W: Expression and comparison of recombinant cholesterol oxidases (COD) in Escherichia coli with native cholesterol oxidase expressed in Brevibacterium sp. Afr J Biotechnol 2011, 10(66):14968-14976.

24. Coulombe R, Yue KQ, Ghisla S, Vrielink A: Oxygen Access to the Active Site of Cholesterol Oxidase through a Narrow Channel is Gated by an Arg-Glu Pair. J Biol Chem 2001, 276(32):30435-30441.

25. Fujishiro K, Uchida H, Shimokawa K, Nakano M, Sano F, Ohta T, Kayahara N, Aisaka K, Uwajima T: Purification and properties of a new Brevibacterium sterolicum cholesterol oxidase produced by E. coli MM294/pnH10. FEMS Microbiol Lett 2002, 215(2):243-248.

26. Doukyu N, Aono R: Purification of Extracellular Cholesterol Oxidase with High Activity in the Presence of Organic Solvents from Pseudomonas sp. Strain ST-200. Appl Environ Microbiol 1998, 64(5):1929-1932.

27. Lyubimov AY, Chen L, Sampson NS, Vrielink A: A hydrogen-bonding network is important for oxidation and isomerization in the reaction catalyzed by cholesterol oxidase. Acta Crystallographica Section D-Biological Crystallography 2009, 65:1222-1231.

28. Sampson NS, Kass IJ, Ghoshroy KB: Assessment of the Role of an $\Omega$ Loop of Cholesterol Oxidase: A Truncated Loop Mutant Has Altered Substrate Specificityt. Biochemistry 1998, 37(16):5770-5778.

29. Studier FW: Protein production by auto-induction in high-density shaking cultures. Protein Expr Purif 2005, 41(1):207-234

doi:10.1186/1472-6750-14-46

Cite this article as: Reiss et al:: Cloning, expression and biochemical characterization of the cholesterol oxidase CgChoA from Chryseobacterium gleum. BMC Biotechnology 2014 14:46.

\section{Submit your next manuscript to BioMed Central and take full advantage of:}

- Convenient online submission

- Thorough peer review

- No space constraints or color figure charges

- Immediate publication on acceptance

- Inclusion in PubMed, CAS, Scopus and Google Scholar

- Research which is freely available for redistribution 